\title{
JUBALAND SAFARI
}

\author{
(For map of Jubaland see Oryx No. 1)
}

By Captain D. S. Sorrell

We left Kismayu by safari truck on the morning of 3rd March, 1950, with the intention of touring the district up to the Kenya border.

We decided to take the Afmadu road, but saw only Dik-Dik on the way, mostly of the greyish Kirk's variety although a few pairs of the prettier Phillips's Dik-Dik were to be secn also. These beautifully-proportioned tiny antelope multiply rapidly in dry bush country such as this, in spite of their many enemies. I have surprised hawks and eagles on a dik-dik "kill" on occasions, and by the neat hole in their skull it has been only too obvious how they were struck down.

We soon reached Afmadu, which is a small nomadic village chiefly notable for its wells. It is here that the Somali tribesmen come to water their thousands of cattle in the dry season. Afmadu is notorious for its numerous Lions, although the males have little or no mane; this may be partly due to the constant rubbing on thorn-bush. The attraction of this arca is, of course, the " casy meat " of the Somalis' cattle and goats. Consequently there is an unending war of spear and arrow versus Lion.

We left Afmadu that evening on the road that leads to Dif and the boundary. After a few minutes driving we entered a group of tall acacia trees where the undergrowth was denser and on turning a bend came into full view of a fine pair of Cheetah, which were walking across the track some forty yards ahead. They were probably looking for their evening meal.

After that we saw several Gerenuk (Waller's Gazelle) belonging to the southern race, peering at us inquisitively with their peculiarly long necks supporting a rather impish-looking face. Dusk was approaching and many Yellow-necked Francolin had come out of the bushes and were scratching about on the track. I shot one of them for my supper. We camped for the night in a clearing among the trees and our arrival disturbed threc immaculate-looking Reticulated Giraffe who were peacefully browsing off the adjacent tree tops. At least the two parents were doing so, but the baby was not yet interested in trees. During the night we were disturbed by the calling of hycanas and the yapping of jackals.

We were on the road again next morning carly, and at this time the bush was cool and fresh; all the fragrant, pleasing 
smells of nature assailed the nostrils. A pair of Bat-eared Foxes scurried out of our path, looking rather sinister with their dark rounded cars and great black bushy tails. After that, more Gerenuk and then three Lesser Kudu does bounded away with a baby between them, their white vertieal stripes plainly visible.

The bush eleared somewhat and stretches of dry grassland came into view and here were small herds of Grant's Gazelle grazing in parties of between five and ten. This race was without the dark lateral band so common in the Northern Frontier Province of Kenya and in S. Ethiopia. Then, on approaching a water-pan which was surrounded by dense growth, a beautiful Lesser Kudu bull broke cover and for a second halted and looked at us, his coat much darker and greyer than the does we had seen earlier, and his spiral horns fully developed. During that morning we had seen several large flocks of Vulturine Guineafowl. The Lesser Bustard was also much in evidence in ones and twos and plenty of pink-eared hares were hopping about.

At this stage the bush began to thin out and trees to become fewer. We continually saw herds of Grant's Gazelle, averaging about twenty head, and smaller herds of Gerenuk. As we neared the Gira Plains a full-grown Leopard crossed our track. It was travelling fast and bounding in its stride; the rosettes of its coat beautifully clear, though appearing rather darker in colour than usual. More Giraffe came into view, all with young ones trailing along behind them.

On the edge of the plains we saw three hen Ostrich, their dull buff plumage blending with the brownish background. Then to our other side we caught a glimpse of a solitary cock bird, resplendent in his magnificent black and white feathers.

The Gira Plains opened up as a great flat expanse of short, parched grassland covering a powdery black cotton soil, with the occasional acacia tree providing relief and shade. During exceptional rains in Kenya this area of Lak Gira is flooded by the surplus waters of the Lorian Swamp. Unfortunately, this does not happen often enough.

I searched the plain with binoculars and saw a lone Beisa Oryx standing under a tree at a distance of about half a mile, and in another direction saw a small herd of what I took to be Soemmering's Gazelle, though on closer inspection they all proved to be Grant's Gazelle does! 'The Soemmering's is rarely seen in this country south of the Juba river.

When later I shot a buck for the pot, the sound of the rifle disturbed a herd of Elephant which had been concealed by tall 
Euphorbia trees, some six hundred yards away. They rushed away across the bush, each beast raising great clouds of dust like a speeding truck. I reckoned that there were about seven or eight of them with two young ones and they had seemed smallish from that distance. When we came upon the spoor we found that their foot-prints measured between twelve and eighteen inches in length.

We turned back to the earth road and by this time the sun was beginning to beat down. Most of the game seemed to have taken cover in the shade of trees and bushes. We saw more Beisa in small parties; they were lazily swishing their tufted tails, and we could see their long straight horns with the distinctive black wine-glass pattern on their faces as they stared at us. Then more Grant's and Gerenuk, sometimes in mixed herds but always with many young.

All this dry bush country was monotonously regular and unrelieved by any hills or other natural features. The giant termite-hills, pointing skywards like great phallic monuments, were everywhere and changed colour with the texture of. the soil-sometimes pale fawn, almost white, and at other times vivid gravel-red. These ant-hills seemed favourite baskingplaces for the smaller creatures and reptiles and we saw many couples of ground squirrels and less often a family of Mongoose of the Sociable Brown variety.

During the morning there had been signs of recent rain along the track; it was drying up quickly now, but a few puddles remained here and there. At a water-pan near to our midday camping-place rested a family of Lesser Kudu and a group of the incredibly ugly grey Wart-Hog; on seeing us the hogs bustled off primly in their military fashion, with tails erect.

I left my camping-place that afternoon with an addition to my escort of Somali retainers. This was a Bon tribesman who stated that he could show me some Hirola-the rare, elusive Hunter's Antelope. I was rather doubtful, especially when, in reply to my questions, he described a Topi to me! I decided to take him along for luck. The day was still very hot and the wild animals were taking their siesta, for on searching in the shady places along the route, we frequently saw gazelle lying down under the trees like cattle, apparently too lazy to get up even when we passed close to them.

The country began to close in as we got nearer to Dif and the thorn-bush became thicker and more dense. We saw only the odd kudu and a few Gerenuk here and there. Disappointed 
at not finding the Hirola, we camped for the night near to the boundary road and just short of Dif.

Next morning we turned south, making for Liboi and the main Mogadishu-Nairobi road. The impenetrable mat of wait-a-bit thorn bush, dotted with a few stunted Commiphora trees, held little game and we saw only stray Gerenuk and Grant's gazelle.

After about two hours travelling however the bush thinned out and the trees grew taller and we came across Giraffe again.

On occasions they were using the sandy road as if they too were on safari and we would follow their tracks thus for many miles until suddenly we would see them on the road ahead, rearing up like giants, their height exaggerated and distorted strangely by the distance and the quivering heat.

Reaching the main road near to Liboi we turned eastwards along it heading back to Kismayu; here we travelled through an area of tall acacia trees where the liver-coloured giraffes were to be seen on all sides. They seemed quite unafraid and we could approach to within thirty yards of them before they took alarm and ran off in their peculiar rolling way, looking as if they were galloping in slow motion.

The soil grew darker after a while and we saw that the ground was carpeted with the spikey, sisal-like elephant grass, which will poison one with its deadly tips if one is foolish enough to walk through it. The Elephant regards it as a succulent delicacy, however, and chews it up in order to get the nourishment and moisture which is inside. Numerous droppings, some of them quite fresh, showed that these giants had been feeding here habitually and regularly. We saw more families of Wart-Hog rooting about in dried up water-pans and dsheiks, the adult males with large fearsome looking up-curling tusks.

A few minutes after arriving at Beles Cogani, which consists of a collection of evil-smelling water-holes supporting a Police and Customs post of neat mud and wattle huts, heavy clouds began to gather. The storm broke over us and it rained torrentially for more than an hour. The earth road was under water when we left the Post in the late afternoon, but fortunately the soil was of red sand and so we managed to get along. However I decided to turn off the main road in order to avoid the gluey black cotton soil which I knew lay ahead, and we took a littleknown short-cut running north-eastwards towards Afmadu.

After the rain there was a delightfully fresh, earthy smell in the air and all the wild life had come out to enjoy the welcome change. The desert rose tree was in blossom with its startlingly 
pink to deep red Howers eontrasting sharply with the ungainly naked branches which bore them.

We soon saw the very fresh prints of Elephant in the rain puddles along the path, and then suddenly we saw a huge grey bulk peering at us through the trees some fifty yards away. He stared for several minutes and stood facing us with his great ears quivering in alarm and annoyance. 'Then he crashed off through the bush following the rain-storm.

All the way to Afmadu we came upon herds of Gerenuk, Grant's Gazelle and parties of Wart-Hog in profusion; the latter splashing about in the mud. Then we saw a beautiful Black-backed Jackal running across our front with some heavy dark object in its mouth. This creature showed up clearly in the half-light with its striking blue-black saddle against rufous limbs. As we drew nearer we saw that the object in its mouth was a Vulturine Guineafowl, plundered from some nearby flock.

It was getting dark as we ploughed our way through the last few miles of water, churned-up mud, and a milling mass of bellowing cattle, to arrive safely once again in Afmadu.

\section{AUSTRALIAN FAUNA CONFERENCE}

An Official Report has reached us on a Conference of Authorities on Australian Fauna and Flora held at Hobart, Tasmania, from 7th to 9th December, 1949. This conference was convened by the Animals and Birds Protection Board of Tasmania, a member of our Society. All States except Queensland were represented.

The Conference was opened by the Attorney-General, Mr. Fagan. The Chair for the first morning was occupied by the Hon. J. J. Dwyer, Minister for Agriculture and Chairman of the Animals and Birds Protection Board, but was then taken over by Dr. J. Pearson, Director of the Tasmanian Museum.

Wild Live Conservation in Australia is entirely the responsibility of the various states, not the Commonwealth Government. The Wild Life Section of the Commonwealth organization C.S.I.R.O. (Commonwealth Scientific and Industrial Research Organization) is for the present entirely concerned with the control of the rabbit.

The following facts emerged about kangaroos, the damage they do, and their protection.

In Queensland kangaroos receive no protection. In New 